Jurnal HELPER, Vol 37 No 2 (2020) 25 - 37

Bimbingan dan Konseling Universitas PGRI Adi Buana Surabaya

ISSN: 02162938

\title{
PENERAPAN STRATEGI PEMODELAN KOGNITIF UNTUK MENINGKATKAN KEBERANIAN TAMPIL DI DEPAN KELAS SISWA PADA MATA PELAJARAN MATEMATIKA
}

\author{
Edi Susanto \\ SMK Negeri 1 Nganjuk \\ edisusanto08011986@gmail.com \\ Trias Endarti \\ SMA Taruna Dra. Zulaeha \\ triasendarti84@gmail.com \\ Rahmat Yanu Srianto \\ SMK Muhammadiyah Watulimo Trenggalek \\ rahmatyanu26@gmail.com \\ Agus Wahyudianto \\ SMK Negeri Pasirian \\ gaguktok01@gmail.com \\ Endah Ruliyatin \\ SMK Negeri 8 Jember \\ endah.ruliyatin10@gmail.com
}

\begin{abstract}
Abstrak
Penelitian ini bertujuan untuk mengetahui adanya peningkatan keberanian tampil di depan kelas siswa pada mata pelajaran matematika antara sebelum dan sesudah diberikan strategi pemodelan kognitif. Subyek dari penelitian ini adalah siswa kelas VII-A di MTsN 1 Bagor Nganjuk yang mempunyai keberanian tampil di depan kelas rendah pada mata pelajaran matematika. Siswa kelas VII-A selurunya berjumlah 34 siswa, yang menjadi subyek dalam penelitian ini berjumlah 5 siswa yang masuk dalam kategori rendah dalam keberanian tampil di depan kelas. Metode pengumpulan data yang digunakan dalam penelitian ini yaitu dengan mengunakan angket dan wawancara sebagai instrument pendukung. Sesuai dengan data yang diteliti, maka penelitian ini tergolong penelitian kuantitatif yang mengunakan metode pre experimental design dengan one group pretes and post test design. Metode analisis yang digunakan adalah statistic nonparametric yaitu uji tanda (sing test) untuk membandingkan anatara pre-test dan post test. Dari hasil analisis dapat diketahui bahwa $\mathrm{x}$ adalah jumlah tanda yang paling sedikit. Hal ini dapat dilihat pada table binominal dari nilai $\rho=0,031$ lebih kecil dari pada $\alpha=0,05$. Strategi pemodelan kognitif dapat meningkatkan keberanian tampil di depan kelas siswa pada mata pelajaran matematika yang ditunjukan adanya perbedaan yang signifikan skor keberanian tampil di depan kelas siswa antara sebelum dan sesudah diberikan penerapan strategi pemodelan kognitif.
\end{abstract}

Kata kunci: Pemodelan Kognitif, Keberanian Tampil di depan kelas 
Jurnal HELPER, Vol 37 No 2 (2020) 25 - 37

Bimbingan dan Konseling Universitas PGRI Adi Buana Surabaya

ISSN: 02162938

\begin{abstract}
The objective of this research is to find out the improvement of students' courage to perform in front of class in mathematics lesson before and treated with cognitive modeling strategy. The subjects of this research are some students of class VII-A of MTsN 1 Bagor Nganjuk who have courage to perform in front of class in mathematics lesson. The total number of class VII-A students is 34, and the subjects of this research are 5 of them who belong to poor category in courage to perform in front of class. The data collecting method used in this research is questionnaire and interview as the supporting instrument. Based on the analyzed data, this research is a quantitative research which uses pre-experimental design method with one group pretest and posttest design. The analysis applied is statistic nonparametrick i.e sing test to compare the pretest and posttest. The analysis result shows that $x$ is the fewest sing. It can be seem from binominal table that $\rho=0.031$ which is smaller than $\alpha=$ 0.05. Cognitive modeling strategy can increase students' courage to perform in front of class in mathematics lesson which is indicated by significant student score different before and after the cognitive modeling strategy applied.
\end{abstract}

Keywords: Cognitive Modeling, Courage to Perform in front of class

\section{LATAR BELAKANG}

Pendidikan merupakan suatu kegiatan mengoptimalkan perkembangan potensi dan kecakapan, serta sebagai salah satu modal untuk mencapai kemajuan bangsa yang sekaligus meningkatkan harkat martabat manusia. Menurut M. Joko Susilo (2006:24) berpendapat bahwa bahwa belajar adalah suatu perilaku. Pada saat siswa belajar, maka respon siswa menjadi lebih baik dalam menerima pelajaran. Sebaliknya, bila siswa tidak belajar maka respon siswa tersebut menurun. Artinya, bahwa seseorang yang mengalami proses belajar akan mengalami perubahan perilaku, yaitu dari tidak mengerti menjadi mengerti, dari tidak bisa menjadi bisa dan dari ragu-ragu menjadi yakin.

Guru merupakan kunci dalam peningkatan mutu pendidikan dan bertanggung jawab untuk mengatur, mengarahkan, serta menciptakan suasana yang mendorong siswa untuk melakanakan kegiatankegiatan di kelas. Untuk menunjang kegiatan di kelas, maka diperlukan pemilihan metode yang tepat dan disesuaikan dengan materi atau konsep yang diajarkan. Semakin banyak siswa dapat mencapai tingkat pemahaman dan penguasaan materi, maka semakin tinggi keberhasilan dari pengajaran tersebut. Keberhasilan dalam pembelajaran 
Jurnal HELPER, Vol 37 No 2 (2020) 25 - 37

Bimbingan dan Konseling Universitas PGRI Adi Buana Surabaya

ISSN: 02162938

dapat diperlihatkan oleh siswa melalui sikap dan perilaku atas apa yang diajarkan disekolah, dan untuk mengajarkan suatu materi pelajaran perlu dikaitkan dengan materi lain yang ada hubungannya dengan materi yang telah dimiliki siswa.

Berdasarkan pengamatan yang dilakukan di MTS Negeri 1 Bagor pada semester genap tahun ajaran 2019/2020, siswa selalu mengeluh tak punya kemampuan apa-apa terutama dalam pembelajaran matematika. Pada pelajaran yang di lakukan di MTS Negeri 1 Bagor hampir sama dengan sekolahan SMP pada umumnya. Mata pelajaran yang matematika jumlahnya sama dengan sekolahan SMP pada umunya yakni dalam 1 minggu ada 3 kali pertemuan. Sedangkan posisi matematika sangat penting sekali dalam menunjang kegiatan belajar. Namun, jika diminta untuk mengerjakan soal di depan kelas, siswa takut secara berlebihan dan merasa tak yakin dengan jawabannya. Selain itu siswa cenderung malu jika jawabanya salah akan mendapat ejekan, tertawaan dari teman-teman sekelas. Menurut siswa pelajaran matematika merupakan pelajaran yang sulit, sehingga setiap kali ada pelajaran matematika siswa yang berani tampil di depan kelas karena di suruh guru bukan karena kemauanya sendiri. Atau hanya duduk diam saat ada pelajaran matematika karena takut jika akan ditunjuk untuk mengerjakan sebuah soal. Hal ini yang menyebakan keberanian siswa tampil di depan kelas menjadi terhambat. Mengingat begitu pentingnya membangun keberanian tampil di depan kelas pada perkembangan siswa sebagai sumber energi (kekuatan) diri anak untuk dapat mengaktualisasikan diri siswa secara utuh, maka siswa membutuhkan bantuan orang tua dan guru. Oleh karena itu, peran guru di sekolah sangatlah penting untuk memahami kesulitan, kelemahan dan hambatannya dalam membangun diri siswa. Untuk meningkatkan keberanian siswa tampil di depan kelas diperlukan pendekatan dalam proses pembelajaran. Hal ini tidak bisa dibiarkan terus menerus karena akan merugikan siswa itu sendiri. Oleh karena itu peningkatan keberanian siswa tampil di depan kelas merupakan salah satu hal yang 
Jurnal HELPER, Vol 37 No 2 (2020) 25 - 37

Bimbingan dan Konseling Universitas PGRI Adi Buana Surabaya

ISSN: 02162938

sangat penting bagi terwujudnya kepribadian individu yang optimal, yang menjadi tujuan dari seluruh komponen pendidikan pada umumnya dan komponen bimbingan dan konseling pada khususnya.

Salah satu bentuk bantuan yang dapat diberikan kepada siswa yang kurang memiliki keberanian tampil di depan kelas adalah melalui pemodelan kognitif, yaitu dengan mengubah pola pikiran saat siswa sedang dihadapkan pada sebuah tugas. Pemodelan kognitif didasarkan pada keyakinan bahwa perilaku menyimpang atau maladaptif siswa disebabkan karena pola pikir yang keliru, oleh karena itu pola pikir yang keliru tersebut dapat dihentikan dan diubah dengan pikiran yang positif. Menurut Kazdin \& Mascitelli (1982) dalam Cormier \& Cormier, strategi pemodelan kognitif sangat efektif untuk mengembangkan kemampuankemampuan siswa terutama kemampuan asertifnya, seperti kepercayan diri tampil di depan kelas. Jadi ketika siswa dihadapkan situasi pada saat pelajaran matematika siswa mampu menumbuhkan rasa keberanian melalui diri sendiri dengan cara merubah cara berfikir yang keliru. Sehingga muncul keberanian tampil di depan kelas dalam mengerjakan soal atau pun menjawab pertanyaan dari guru. Oleh karena itu pemodelan kogitif sangatlah tepat sebagai strategi yang digunakan untuk meningkatkan pola berfikir siswa sehingga mampu bertindak dalam menghadapi suatu tugas ataupun permasalahan sepertihalnya dalam peningkatan keberanian siswa tampil didepan kelas pada pelajaran matematika.

Berdasarkan fakta dan uraian di atas, maka peneliti tertarik untuk meneliti penerapan strategi pemodelan kognitif untuk meningkatkan keberanian siswa tampil di depan kelas pada mata pelajaran Matematika Kelas VII-A MTS Negeri 1 Bagor Nganjuk.

\section{METODOLOGI PENELITIAN}

Penelitian ini menggunakan penelitian kuantitatif. Penelitian ini menggunakan pre-experimental design dengan bentuk one-group pretestposttest design. Dikatakan preexperimental design karena desain ini belum merupakan eksperimen sungguh-sungguh. Hal ini karena 
Jurnal HELPER, Vol 37 No 2 (2020) 25 - 37

Bimbingan dan Konseling Universitas PGRI Adi Buana Surabaya

ISSN: 02162938

masih terdapat variabel luar yang ikut berpengaruh terhadap terbentuknya variabel terikat. Jadi hasil eksperimen yang merupakan variabel terikat itu bukan semata-mata dipengaruhi oleh variabel bebas. Hal ini dapat terjadi, karena tidak adanya variabel kontrol, dan sampel tidak dipilih secara random (Sugiyono,2008). Pengukuran pada penelitian ini dilakukan sebanyak dua kali yaitu sebelum dan sesudah penelitian. Pengukuran pertama (pretest) dilakukan pada satu kelompok subjek dengan menggunakan angket keberanian tampil di depan kelas. Selanjutnya diberikan treatment atau perlakuan dalam jangka waktu tertentu, kemudian dilakukan pengukuran kembali (posttest).

Pada Tahap perencanaan onegroup pretest-posttest design yang akan dilaksanakan pada peneliti menyusun; (1) Memberikan pre-test untuk mengukur tingkat keberanian siswa tampil di depan kelas pada mata pelajaran Matematika siswa kelas VIIA MTS Negeri 1 Bagor sebelum diberi perlakuan, (2) Memberikan perlakuan (pemberian latihan strategi pemodelan kognitif) pada siswa kelas VII-A MTS Negeri 1 Bagor yang memiliki keberanian rendah tampil di depan kelas, (3) Memberikan post-test untuk mengukur tingkat keberanian tampil didepan kelas pada mata pelajaran Matematika siswa kelas VII-A MTS Negeri 1 Bagor sesudah diberi perlakuan, (4) Membandingkan pretes dan post-tes untuk mengetahui ada tidaknya perbedaan skor keberanian tampil di depan kelas siswa kelas VIIA MTS Negeri 1 Bagor pada mata pelajaran Matematika.

Tahap Pelaksanaan Penelitian; (1) Menyusun jadwal penelitian, Jadwal penelitian disesuaikan dengan kegiatan belajar mengajar siswa kelas VII-A di MTS Negeri 1 Bagor Nganjuk. Sehingga, penelitian tidak mengganggu kegiatan belajar mengajar di kelas, (2) Pengumpulan data menggunakan skala pengukuran untuk mengetahui skor keberanian tampil di depan kelas setelah penerapan strategi pemodelan kognitif. Prosedur penelitian yakni, Pretest Menyebarkan angket untuk mengetahui tingkat keberanian siswa tampil di depan kelas, dengan menggunakan angket yang sudah valid dan reliabel untuk menghasilkan skor keberanian siswa tampil di depan kelas. Perlakuan menggunakan 
Jurnal HELPER, Vol 37 No 2 (2020) 25 - 37

Bimbingan dan Konseling Universitas PGRI Adi Buana Surabaya

ISSN: 02162938

Penerapan Strategi Pemodelan Kognitif untuk meningkatkan keberanian tampil di depan kelas siswa. Posttest menyebarkan angket untuk mengetahui tingkat keberanian siswa tampil di depan kelas, antara hasil skor pretest dibandingkan dengan hasil skor posttest yang sudah diberikan perlakuan. Untuk mendapatkan hasil perbandingan skor pretest dan posttest. Analisis data menggunakan uji jenjang-bertanda Wilcoxon. Peneliti melakukan pembahasan yang mendalam tentang hasil penelitian berdasarkan data-data yang diperoleh dan analisis yang digunakan.

Sumber data dalam penelitian adalah subjek dari mana data diperoleh. Subjek penelitian dapat berupa orang, tempat, atau simbol. Adapun yang menjadi subjek dalam penelitian ini adalah siswa kelas VII-A MTS Negeri 1 Bagor yang mempunyai skor rendah dalam keberanian tampil di depan kelas pada mata pelajaran matematika yang diukur melalui angket Keberanian Tampil di depan kelas.

Pada observasi nonpartisipan, peneliti tidak terlibat langsung dengan aktivitas siswa yang diamati dan hanya sebagai pengamat independen (Sugiyono, 2008). Peneliti meminta bantuan guru Matematika kelas VII-A untuk melakukan observasi terhadap subjek penelitian, yaitu perubahan dalam peningkatan keberanian tampil di depan kelas.

Angket yang diberikan menggunakan jenis angket tertutup dalam bentuk checklist. Sedangkan skala yang dipakai adalah skala Likert. Skala Likert digunakan untuk mengukur sikap, pendapat, dan persepsi seseorang atau sekelompok orang tentang fenomena sosial. Jawaban setiap butir instrumen yang menggunakan skala Likert mempunyai gradasi dari sangat positif sampai sangat negatif (Sugiyono,2008). Angket yang diberikan telah disediakan 4 (empat) pilihan jawaban, sehingga siswa menjawab dengan cara memberikan tanda check $(\sqrt{ })$ pada jawaban yang dianggap sesuai dengan dirinya. Peneliti menggunakan 4 gradasi yang berupa kata-kata: selalu, sering, kadang-kadang, dan tidak pernah. Pemberian angket bertujuan untuk mengetahui siswa yang mempunyai skor keberanian tampil di depan kelas rendah.

Analisis data pada penelitian ini 
Jurnal HELPER, Vol 37 No 2 (2020) 25 - 37

Bimbingan dan Konseling Universitas PGRI Adi Buana Surabaya

menggunakan uji jenjang-bertanda Wilcoxon (Wilcoxon's Signed Rank Test). Uji jenjang-bertanda Wilcoxon merupakan penyempurnaan uji tanda sebelumnya. Uji ini diperkenalkan oleh Frank Wilcoxon di tahun 1945. Dalam uji jenjang-bertanda Wilcoxon ini, disamping tanda positif atau negatif, besarnya beda juga diperhitungkan. Sedangkan dalam uji tanda besarnya selisih angka antara positif dan negatif tidak diperhitungkan. Seperti dalam uji tanda, teknik ini digunakan untuk menguji signifikansi hipotesis komparatif dua sampel yang berkorelasi bila datanya berbentuk ordinal atau berjenjang (Djarwanto,2003)

Langkah-langkah yang diperlukan dalam pengujian ini ialah: (1) Berikan jenjang (rank) untuk tiap-tiap beda dari pasangan pengamatan $\left(\mathrm{Y}_{\mathrm{i}}-\mathrm{X}_{\mathrm{i}}\right)$ sesuai dengan besarnya, dari yang terkecil sampai terbesar tanpa memperhatikan tanda dari beda itu (nilai beda absolut). Bila ada dua atau lebih beda yang sama, maka jenjang untuk tiap-tiap beda adalah jenjang rata-rata. (2) Bubuhkan tanda positif atau negatif pada jenjang untuk tiaptiap beda sesuai dengan tanda dari beda itu. Beda 0 tidak diperhatikan. (3) Jumlahkan semua jenjang bertanda + atau semua jenjang bertanda -, bergantung dari mana yang memberikan jumlah yang lebih kecil setelah tandanya dihilangkan. Notasikan jumlah jenjang yang lebih kecil ini dengan T. (4) Bandingkan nilai $\mathrm{T}$ yang diperoleh dengan nilai $\mathrm{T}$ untuk uji-jenjang bertanda Wilcoxon. Kriteria pengambilan keputusan adalah sebagai berikut: $H_{0}$ diterima apabila $\quad T_{\text {hitung }} \geq T_{\text {tabel }} . \quad H_{0}$ ditolak apabila $T_{\text {hitung }}<T_{\text {tabel }}$. Dimana $T_{\text {tabel }}=$ $\mathrm{T}_{(\alpha, \mathrm{db})}$, Tabel nilai $\mathrm{T}$ hanya untuk $\mathrm{n} \leq$ 25. Untuk pasangan yang lebih banyak daripada $25(\mathrm{n}>25)$, tabel nilai $\mathrm{T}$ tidak dapat dipergunakan. (Djarwanto,2003). $H_{0}$ atau hipotesis nihil penelitian ini adalah "Tidak ada peningkatan skor Penerapan strategi pemodelan kognitif terhadap keberanian siswa tampil di depan kelas VII-A MTS Negeri 1 Bagor Nganjuk". $H_{a}$ atau hipotesis alternatif penelitian ini adalah "Ada peningkatan skor Penerapan strategi pemodelan kognitif terhadap keberanian siswa tampil di depan kelas VII-A MTS Negeri 1 Bagor Nganjuk". 
Jurnal HELPER, Vol 37 No 2 (2020) 25 - 37

Bimbingan dan Konseling Universitas PGRI Adi Buana Surabaya

ISSN: 02162938

\section{HASIL PENELITIAN}

Berdasarkan hasil penelitian yang dilakukan terhadap 34 siswa kelas VII-A MTs-Negeri 1 Bagor Nganjuk, diketahui terdapat 5 siswa yang memiliki tingkat keberanian tampil di depan kelas rendah yaitu buah apel, buah nanas, buah jeruk, buah angur, dan buah mangga. Selanjutnya kelima siswa yang memiliki keberanian siswa tampil di depan kelas rendah tersebut diberikan bantuan perlakuan yang berupa penerapan strategi pemodelan kognitif.

Tabel 1 Subyek Dengan Skor Keberanian Tampil Di Depan Kelas Rendah

\begin{tabular}{|c|l|r|l|}
\hline No. & \multicolumn{1}{|c|}{$\begin{array}{c}\text { Nama } \\
\text { Subjek }\end{array}$} & Skor & Kategori \\
\hline 1. & Buah Apel & 75 & Rendah \\
\hline 2. & Buah Nanas & 78 & Rendah \\
\hline 3. & Buah Jeruk & 75 & Rendah \\
\hline 4. & $\begin{array}{l}\text { Buah } \\
\text { Anggur }\end{array}$ & 77 & Rendah \\
\hline 5. & $\begin{array}{l}\text { Buah } \\
\text { Mangga }\end{array}$ & 77 & Rendah \\
\hline
\end{tabular}

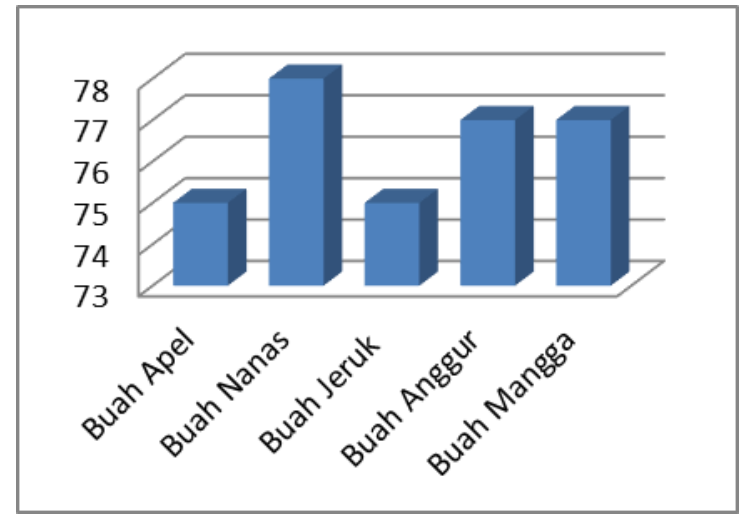

Grafik 1 Hasil Pret-test Angket Keberanian Tampil Di Depan Kelas
Tabel 2 Hasil Post test Angket Keberanian Tampil Di Depan Kelas

\begin{tabular}{|l|l|r|c|}
\hline No & \multicolumn{1}{|c|}{ Subjek } & Skor & Keterangan \\
\hline 1 & Buah Apel & 95 & Sedang \\
\hline 2 & $\begin{array}{l}\text { Buah } \\
\text { Nanas }\end{array}$ & 90 & Sedang \\
\hline 3 & Buah Jeruk & 85 & Sedang \\
\hline 4 & $\begin{array}{l}\text { Buah } \\
\text { Anggur }\end{array}$ & 97 & Sedang \\
\hline 5 & $\begin{array}{l}\text { Buah } \\
\text { Mangga }\end{array}$ & 89 & Sedang \\
\hline
\end{tabular}


Jurnal HELPER, Vol 37 No 2 (2020) 25 - 37

Bimbingan dan Konseling Universitas PGRI Adi Buana Surabaya

ISSN: 02162938

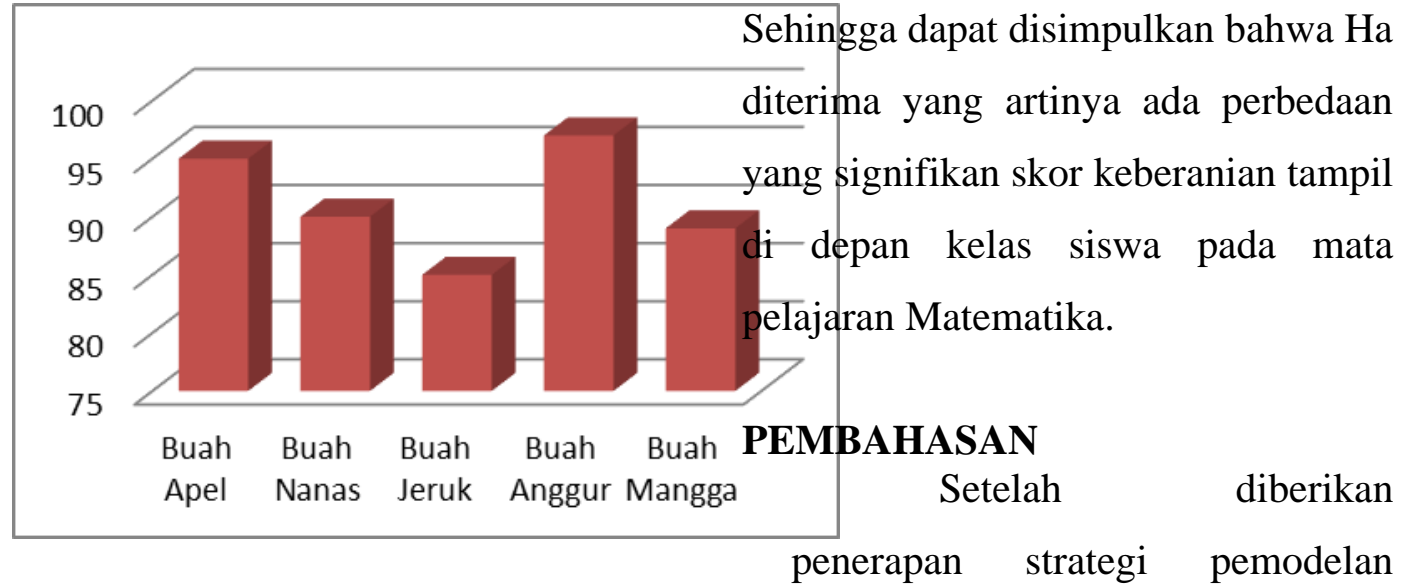

Grafik 2 Data Hasil Post-test Angket Keberanian Tampil Di Depan Kelas

kognitif terhadap kelima siswa tersebut, ternyata didapatkan hasil yaitu adanya peningkatan keberanian siswa tampil di depan

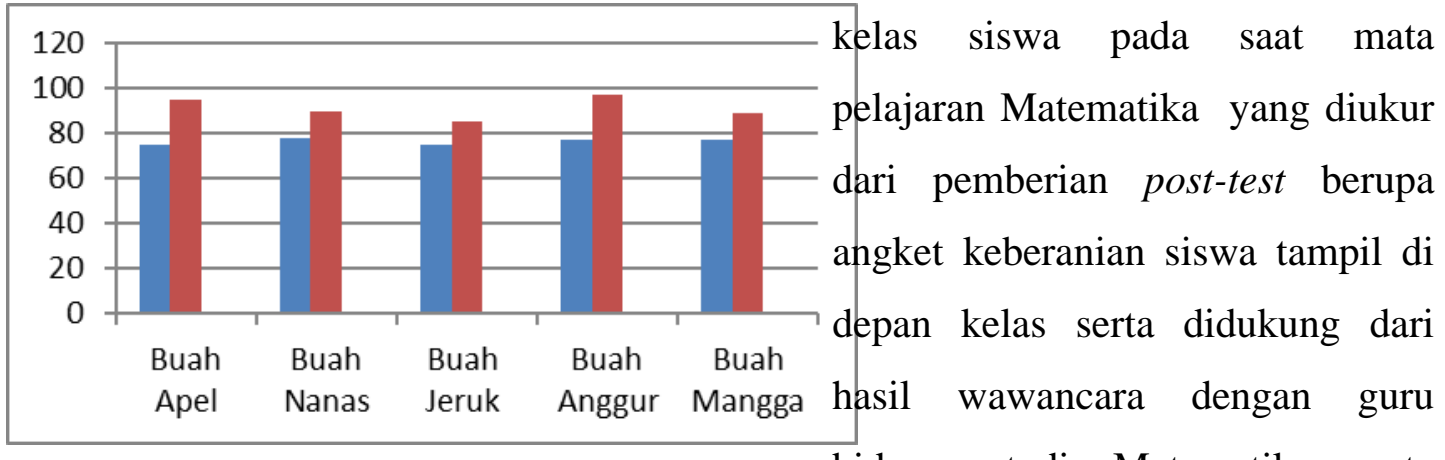
bidang studi Matematika serta

\section{Grafik 3 Hasil pre-test dan Post-test}

\section{Angket Keberanian Tampil di}

\section{depan kelas}

Tabel dan grafik diatas menunjukkan arah perubahan yang positif karena ada peningkatan nilai dari pre-test (XA) ke post-test (XB). Tabel diatas juga menunjukkan $\rho$ lebih kecil dari sehingga Ho ditolak dan $\mathrm{Ha}$ diterima. Hal ini dapat dilihat dari nilai $\rho=$ 0,031 lebih kecil dari $\square=0,05$. observasi langsung terhadap subjek penelitian. Berdasarkan hasil wawancara dengan Guru Matematika, diketahui bahwa siswa yang sebelumnya pasif dalam mengajukan pertanyaan ketika pelajaran Matematika, Buah Anggur sudah menunjukkan perubahan sedikit demi sedikit. Siswa buah jeruk dan buah nanas juga sudah dapat menunjukkan sikap asertifnya di dalam kelas dengan memberanikan diri untuk 
Jurnal HELPER, Vol 37 No 2 (2020) 25 - 37

Bimbingan dan Konseling Universitas PGRI Adi Buana Surabaya

ISSN: 02162938

bertanya kepada guru ketika menemui kesulitan pada saat pelajaran Matematika berlangsung. Sedangkan berdasarkan hasil observasi yang dilakukan oleh peneliti terhadap kelima siswa yang menjadi subjek penelitian, diperoleh hasil bahwa kelima subjek penelitian yaitu buah apel, buah nanas, buah jeruk, buah mangga, dan buah apel telah banyak menunjukkan perubahan perilaku yang positif di dalam kelas ketika pelajaran Matematika. Kelima siswa tersebut sudah mulai berani tampil di depan kelas walaupun masih terlihat kaku dan ragu-ragu. Namun hal ini sudah menunjukkan bahwa ada peningkatan keberanian tampil di depan kelas.

Berdasarkan hasil uji tanda, diketahui $\rho=0,031$ dan harga ini lebih kecil dari nilai $\square=$ 0,05 yang artinya Ho ditolak dan Ha diterima. Ini berarti ada perbedaan tingkat keberanian siswa tampil di depan kelas pada mata pelajaran Matematika yang signifikan antara sebelum dan sesudah diberikan perlakuan yang berupa strategi pemodelan kognitif.
Perbedaan tersebut menunjukkan perbedaan yang positif, yaitu meningkatnya keberanian siswa tampil di depan kelas ketika pelajaran Matematika berlangsung. Namun diharapkan keberanian siswa tampil di depan kelas ini tidak hanya terbatas pada mata pelajaran Matematika saja, tetapi juga pada semua mata pelajaran.

Pada penelitian ini strategi pemodelan kognitif digunakan sebagai usaha untuk membantu siswa ketika dihadapkan pada suatu kejadian atau sebuah tugas yang menuntutnya untuk melakukan sesuatu. Hal ini sesuai dengan pendapat Sarason dalam Cormier (1985:379) bahwa strategi pemodelan kognitif merupakan suatu prosedur dimana seorang konselor menunjukkan kepada seseorang tentang apa yang harus dilakukannya pada saat dihadapkan pada sebuah tugas.

Pada pelaksanaan penelitian, para konseli dan konselor melaksanakan langkahlangkah sesuai dengan hal-hal yang telah ditentukan sebelumnya. Dimulai dengan pelaksanaan tes awal (pre-test), pemberian 
Jurnal HELPER, Vol 37 No 2 (2020) 25 - 37

Bimbingan dan Konseling Universitas PGRI Adi Buana Surabaya

perlakuan (strategi pemodelan kognitif) dan pelaksanaan yang terakhir adalah tes akhir (post-test). Pada tes awal (pre-test) dan tes akhir (post-test) siswa diberikan instrumen yang berupa angket keberanian siswa tampil di depan kelas pada mata pelajaran Matematika. Hasil yang diperoleh ialah strategi pemodelan kognitif ini dapat meningkatkan keberanian siswa tampil di depan kelas terutama pada mata pelajaran Matematika. Pada konseli buah apel mengalami peningkatan skor dari 75 menjadi 95, konseli buah mangga mengalami peningkatan dari skor 78 menjadi 90, konseli buah jeruk mengalami peningkatan skor dari 75 menjadi 85, konseli buah anggur mengalami peningkatan skor dari 77 menjadi 97 dan peningkatan skor dari 77 menjadi 89 pada konseli buah apel. Pada pelaksanaan konseling ini tidak terdapat kendala yang berarti selama kegiatan ini berlangsung. Baik dari segi tempat, petunjuk pelaksanaan, karakter siswa, maupun bahasa yang digunakan. Hanya keterbatasan waktu saja yang sedikit menghambat dalam pelaksanaan konseling ini, hal ini disebabkan karena waktu penelitian mendekati waktu Ujian Akhir Sekolah, sehingga pelaksanaan konseling disesuaikan dengan kondisi atau waktu luang siswa. Masalah waktu dapat diatasi dengan cara memberikan perlakuan (strategi pemodelan kognitif) pada jam istirahat, setelah pulang sekolah, atau waktu-waktu tertentu yang sekiranya tidak mengganggu aktivitas belajar siswa di sekolah, sehingga masalah keterbatasan waktu dapat diatasi.

Beberapa hasil penelitian yang dapat ditemukan, antara lain: (1) Siswa menjadi lebih aktif dan berani untuk mengajukan pertanyaan kepada guru saat pelajaran Matematika ketika mereka menemui kesulitan pada materi yang diajarkan. (2) Setelah diberikan penerapan strategi pemodelan kognitif, cara berfikir siswa menjadi lebih terencana ketika dihadapkan pada suatu tugas atau kejadian. Sehingga siswa dapat melakukan tugasnya dengan lebih baik. (3) Berdasarkan perhitungan dengan tes tanda (sign test) 
Jurnal HELPER, Vol 37 No 2 (2020) 25 - 37

Bimbingan dan Konseling Universitas PGRI Adi Buana Surabaya

ISSN: 02162938

didapatkan hasil $\rho=0,031$ dan $\alpha=$ 0,05. Maka $\rho$ lebih kecil dari $\alpha$, yang berarti ada peningkatan skor keberanian siswa tampil di depan kelas pada mata pelajaran Matematika antara sebelum dan sesudah diberikan penerapan strategi pemodelan kognitif.

\section{KESIMPULAN DAN SARAN}

Berdasarkan hasil analisis data sebagaimana yang telah diuraikan pada bagian hasil penelitian di atas, dapat disimpulkan sebagai berikut. Tindakan strategi pemodelan kognitif secara signifikan tidak dapat meningkatkan meningkatkan keberanian siswa tampil di depan kelas VII-A MTS Negeri 1 Bagor Nganjuk. Berdasarkan hasil penelitian tersebut, peneliti menyarankan sebagai berikut. Pertama, perlu dilakukan penelitian lagi dengan menambah jumlah pertemuan variabel tindakan strategi pemodelan kognitif misalnya selama satu semester.

\section{DAFTAR RUJUKAN}

Alwisol. 2006. Psikologi Kepribadian. Malang: UMM Press

Angelis, Barbara De. 2005. Confidence: Percaya Diri
Sumber Sukses dan

Kemandirian. Jakarta:

Gramedia Pustaka Utama.

Arikunto, Suharsimi. 2006. Prosedur Penelitian. Jakarta: PT. Rineka Cipta.

Azwar, Saifuddin. 2003. Penyusunan Skala Psikologi. Yogyakarta: Pustaka Pelajar Offset.

Corey, Gerald. 2007. Teori dan Praktek Konseling dan Psikoterapi. Bandung: Refika Aditama.

Cormier \& Cormier. 1985. Interviewing Strategies for Helpers. California: Brooks/Cole Publishing Company.

Davies, Philippa. 2004. Meningkatkan Rasa Percaya Diri: Increasing Confidence. Jogjakarta: Torrent Books.

Djarwanto. 2003. Statistik Nonparametrik. Yogyakarta: BPFE.

Faisal. Sanapiah. 1981. Dasar dan Teknik Menyusun Angket. Surabaya: Usaha Nasional.

Gunarsa, Singgih, D. 2003. Konseling dan Psikoterapi, Jakarta: PT. Gunung Mulia

Hadi, Sutrisno. 2004. Statistik: Jilid 2. Yogyakarta: Andi Offset.

Hakim, Thursan. 2002. Mengatasi Rasa Tidak Percaya Diri. Jakarta: Puspa Swara. 
Jurnal HELPER, Vol 37 No 2 (2020) 25 - 37

Bimbingan dan Konseling Universitas PGRI Adi Buana Surabaya

ISSN: 02162938

Lie, Anita. 2003. 101 Cara Menumbuhkan Percaya Diri Anak. Jakarta: PT. Elek Media Komputindo.

Lindenfield, Gael. 1997. Mendidik Anak Agar Percaya Diri. Jakarta: Arcan.

Masrul. M.H, Abdulah. 2000. Membina Keberanian, Jatim : Putra Pelajar

Mastuti, Indari. 2008. 50 Kiat Percaya Diri. Jakarta: Hi-Fest Publishing. Mertodipuro, Sumantri. 1978.

Keberanian Hasan pribadi. Jakarta:

Gunung Jati.

Nursalim, Mochamad. 2005. Strategi Konseling. Surabaya. Unesa University Press.

Roger Natalie, 2000. Berani Berbicara dan Tampil Di Depan Umum. Lala Herawan D. Penerjemah, Nisa Cendekia: Bandung

Santrock, John W. 2003. Adolescence: Perkembangan Remaja. Jakarta: Erlangga.

Sugiyono. 2008. Metode Penelitian Kuantitatif : Lengkap dengan Pendekatan $R \& D$. Bandung: Alfa Beta

Sujanto, Agus, 1991. Psikologi Umum. Surabaya Bumi Aksara.

Sukardi, Dewa Ketut (1988). Bimbingan dan Konseling, Jakarta Bumi Aksara.

Tim, 1995, Kamus Besar Bahasa Indonesia. Jakarta: PT. Balai Pustaka.
Winkel. W.S, (1988). Bimbingan dan Konseling di Institusi Pendidikan. Jakarta: Grasindo 